Florida International University FIU Digital Commons

$11-12-2010$

\title{
The effect of after-school music programs in at-risk students' self-esteem and social skills in San Juan, Puerto Rico
}

Carmen D. Collazo

Florida International University

DOI: $10.25148 /$ etd.FI14060875

Follow this and additional works at: https:// digitalcommons.fiu.edu/etd

Part of the Music Education Commons

\section{Recommended Citation}

Collazo, Carmen D., "The effect of after-school music programs in at-risk students' self-esteem and social skills in San Juan, Puerto Rico" (2010). FIU Electronic Theses and Dissertations. 2405.

https://digitalcommons.fiu.edu/etd/2405 
Miami, Florida

THE EFFECT OF AFTER-SCHOOL MUSIC PROGRAMS IN AT-RISK STUDENTS'

SELF-ESTEEM AND SOCIAL SKILLS IN SAN JUAN,

PUERTO RICO

A thesis submitted in partial fulfillment of the

requirements for the degree of

MASTER OF MUSIC

by

Carmen D. Collazo 
To: Acting Dean Brian Schriner

College of Architecture and the Arts

This thesis, written by Carmen D. Collazo, and entitled The Effect of After-School Music Programs in At-Risk Students' Self-Esteem and Social Skills in San Juan, Puerto Rico, having been approved in respect to style and intellectual content, is referred to you for judgment.

We have read this thesis and recommend that it be approved.

Adriana McEachern

Joel Galand

Kathleen Kerstetter, Major Professor

Date of Defense: November 12, 2009

The thesis of Carmen D. Collazo is approved.

Acting Dean Brian Schriner College of Architecture and the Arts

Interim Dean Kevin O'Shea University Graduate School

Florida International University, 2010 


\section{DEDICATION}

I want to dedicate this thesis to the entire music faculty, staff, and most importantly, students at the Programa de Orquestas Sinfónicas Juveniles (POSJU).

Without them this work would not have been done. I also want to dedicate this work to my family and friends. Thanks for your constant love, understanding, and support through the distance. I love you all. 


\section{ACKNOWLEDGMENTS}

I first wish to acknowledge the members of my committee for their support, patience, and especially for their guidance in executing this research project. Second, I wish to thank Ms. Magaly Matos and the POSJU staff at the Felipe Gutierrez y Espinoza school in el sector de Villa Prades, San Juan P.R., who helped me in countless ways. I could not have completed this project without them. Finally, I wish to acknowledge all the people who helped me directly or indirectly accomplish this dream. 


\author{
ABSTRACT OF THE THESIS \\ THE EFFECT OF AFTER-SCHOOL MUSIC PROGRAMS IN AT-RISK STUDENTS' \\ SELF-ESTEEM AND SOCIAL SKILLS IN SAN JUAN, PUERTO RICO \\ by \\ Carmen D. Collazo
}

Florida International University, 2010

Miami, Florida

Professor Kathleen Kerstetter, Major Professor

The purpose of this study was to examine and expand upon the role the Programas de Orquestas Sinfónicas Juveniles (POSJU) experiences play in self-esteem and social skills. The research took place in Felipe Gutierrez y Espinoza School, one of ten POSJU centers, located in the San Juan, Puerto Rico. Thirty-eight students $(\mathrm{N}=38)$ aged 7 to 17 participated in this study. Participants rated their self-esteem and social skills using the Rosenberg Self-Esteem Scale (RSES) and the Social Skills Competence Checklist (SSCC). No significant differences between pre- and post-evaluations on RSES and SSCC were found. For additional information, teachers evaluated all participants using the Teacher Student Report (TSR). Significant differences were found across the construct of social skills, but not self-esteem. Information regarding the POSJU after school program was collected from parents through a Parent Questionnaire Report (PQR). Overall, parents' responses towards the program show satisfaction with POSJU. 


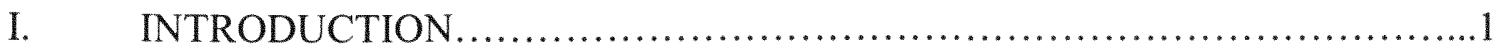

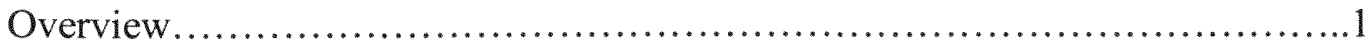

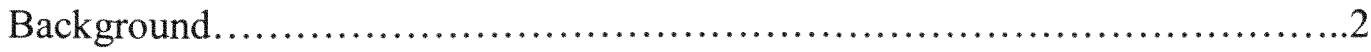

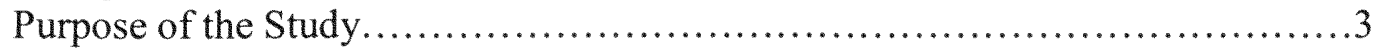

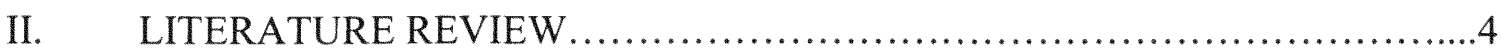

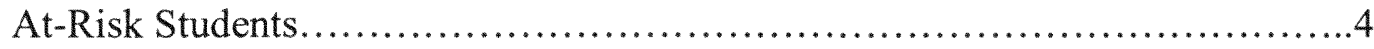

Self-Esteem............................................................... 5

Social Skills............................................................

Music, Self-Esteem, Social Skills, and At-risk Students.........................8

After-School Programs...................................................9

III. METHODOLOGY.....................................................11

Design and Procedure....................................................11

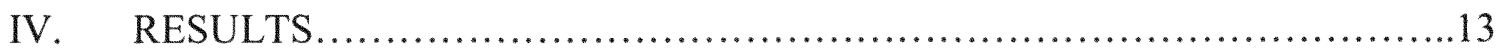

Overview.............................................................. 13

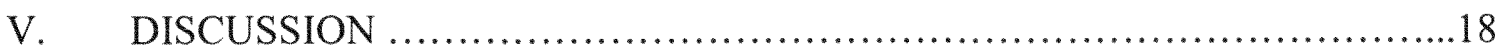

Research Objectives.................................................. 18

Study Limitations......................................................... 19

Future Suggestion.................................................... 19

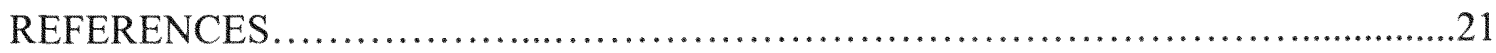

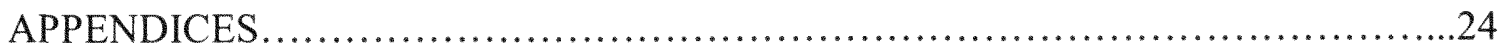




\section{CHAPTER 1}

\section{INTRODUCTION}

\section{Overview}

The purpose of this study was to document and expand upon how participation in the after-school program, Programa Orquesta Sinfónica Juveniles of Puerto Rico, affects the self-esteem of members. Currently, thousands of Puerto Rican students face the challenge of living in high-risk communities and neighborhoods. Poverty, alcoholism, drug abuse, and teen pregnancies are just some of the factors that prevent students from participating successfully in school. The number of students mired in such conditions is increasing. In 2005, the Puerto Rico Health Department reported that $17.6 \%$ of the 50,687 births on the island were from adolescent mothers between the ages of 15 and 19 years old and $0.4 \%$ from pre-adolescents between 10 and 14 years. By $20026.8 \%$ of 15 to-17 year olds reported using alcohol, and 1.2\% reported using illicit drugs (Universidad de Puerto Rico, n.d.). While these statistics suggest relatively low rates compared to the mainland United States, factors such as alcohol, drugs, and teen pregnancies, contribute to lower academic achievement, foster negative behavioral problems, and worsen physical and emotional health (Donnelly, 1987).

Researchers have identified multiple conditions that are associated with being atrisk, including the following: living in unstable school districts, belonging to a lowincome or single-parent family, exhibiting low academic skills, or having parents who are not high school graduates (Durian \& Butler, 1987). To these contributing factors, Dougherty (1990) and Taylor, Barry, and Wells (1997) have added low self-esteem. A common definition of self-esteem is a person's subjective appraisal of himself or herself 
as positive or negative (Benedetto, n.d.). Self-esteem affects the ways in which

individuals interact with peers, handle situations, make decisions, and set personal goals. Some common characteristics of low self-esteem include little or no interest in learning, lack of focus and motivation, and fear of risk taking (Benedetto, n.d.).

At-risk students need positive reinforcement, which is best offered in a structured environment, such as that provided by school. When a student experiences failure and falls behind academically, school becomes a negative environment that reinforces low self-esteem (Donnelly, 1987). Participating in a musical group can provide the kind of structure within which self-expression and feelings of self-worth may thrive (Durksen \& Darrow, 1991).

\section{Background}

The Programa de Orquestas Sinfónicas Juveniles (POSJU) is part of the services offered by the Corporación de las Artes Musicales (CAM) in San Juan, Puerto Rico. The CAM is a public corporation of the Common Wealth of Puerto Rico. This organization is responsible for promoting and encouraging the enrichment of music on the island. The CAM offers different programs, including Corporación de la Orquesta Sinfónica de Puerto Rico (COSPR), Festival Casals, Festival Iberoamericano de las Artes (FIA), Festival de la Orquesta Sinfónica Juvenil de las Américas (FOSJA), Programa Educativo Conoce a tu Orquesta (PEDCO), and Programas de Orquestas Sinfónicas Juveniles (POSJU). POSJU is an after-school music program dedicated to at-risk students living in identified, low socio-economic communities within the San Juan area. The principal objective of the program is to enhance the life of Puerto Rican students and their communities using music as an agent of social transformation. 
After-school outreach activities are increasingly attracting attention and funding because of the awareness that children from at-risk neighborhoods need supervised, safe, and constructive focus during the hours following school (Shumow, 2001). A report commissioned by the Boston After-School for All Partnerships Research states that high quality after-school programs could help students overcome critical barriers to learning, thereby supporting academic achievement and well-being (Hall, Yohalem, Tolman, \& Wilson, 2003).

\section{Purpose of the Study}

The purpose of this study was to examine critically how the experience of participating in POSJU's after-school program contributes to developing self-esteem and social skills. Specific questions to be answered are:

1) To what extent, if any, does participation in POSJU influence social skills?

2) To what extent, if any, does participation in POSJU influence self-esteem?

3) How do parents value POSJU?

The next section, Chapter Two, explains the concepts of self-esteem with regard to social skills. It also discusses the importance of after-school program participation and positive influences on at-risk students. Chapter Three describes the research method used in the investigation. Chapters Four and Five report and discuss the results and their implications for the future. 


\section{CHAPTER 2}

\section{LITERATURE REVIEW}

\section{At-risk Students}

A clear indication of the magnitude of concern over at-risk students is the large amount of literature on the topic. Many researchers use the term at-risk to denote a high probability for dropping out of school, but it also connotes negative factors within a student's life. Specific conditions and behaviors classify students as at-risk. These factors can be divided into two categories: (1) Descriptive characteristics or "antecedents" that place students at-risk; (2) "High-risk behaviors" in which the at-risk tendency becomes manifested when the student encounters problems within the school and society (Dryfoos, 1990 as cited in Taylor, Barry, \& Walls, 1997). There are many antecedents identified in the research literature including dysfunctional families; the stress of economic deprivation; emotional, psychological, and physical abuse; and minority status.

In trying to arrive at a comprehensive description of at-risk students, Robinson (2004) interviewed seven master teachers in order to identify descriptive characteristics and teaching methods that positively contribute to handling at-risk students in the music classroom. All seven teachers gave a different definition of the term at-risk but came to the same conclusion: at-risk should refer to a causal relationship between factors. These factors include any situation, condition, or characteristic that increases the possibility of an undesired outcome.

There is an extensive list of undesired outcomes. Duerksen (1991) identified some negative outcomes as doing poorly or dropping out of school, negative verbal interaction between students and teachers, discipline problems, negative self-perception, poor 
emotional health, and loneliness. The report Music and At-Risk: Creative Solutions for a National Dilemma (MENC: The National Association for Music Educations, 1997) adds the following: truancy, school failure, rebellious attitude, delinquency, substance abuse, emotional problems, and low self-esteem. Students do not suddenly become at-risk; there is a chain of events that occurs and frequently begins at an early age (Taylor, Barry, \& Wells, 1997). Therefore, early identification of at-risk students is a preventive measure.

Music educators have the chance to help students refine their aesthetic capacity to experience the beautiful, a capacity not always nurtured in the at-risk student (Duerksen \& Darrow, 1991). Music activities can provide the opportunity for creative selfexpression and promote a sense of gratification, accomplishment, and self-esteem; they are often a motivating factor that keeps students engaged in school. Within the framework of musical activities, students can learn discipline, cooperation, teamwork, structure, and a sense of belonging. No one assumes that music can cure an addict or supplant students' use of drugs (Duerksen, 1991); however, it can assist in alleviating some of the problems that lead students to patterns of social isolation, low self-esteem, poor emotional health, lack of motivation, and lack of interest in leisure activities.

\section{Self-Esteem}

Self-esteem has been the object of much research. Some define self-esteem as the way in which humans appreciate their intrinsic value (Benedetto, n.d). Self-esteem is also significantly associated with personal satisfaction and effective functioning, and it can vary depending on experience, gender, age, and other role-defining conditions. Coopersmith (1967) refers to self-esteem as an evaluation the individual makes and maintains about the self, it also expresses an attitude of approval or disapproval. Self- 
esteem indicates the extent to which individuals believe themselves to be capable, significant, successful, and valuable. Concisely, it is a personal judgment of worthiness expressed in the attitudes individuals holds towards themselves (Coopersmith, 1967).

Self-esteem is an emotional experience in response to evaluations about personal worth. The organization Self-Esteem International defines self-esteem as the evaluative function of self-concept (www.self-esteem-international.org). Robert Reasoner states that self-esteem has a strong connection with competence, worthiness, and their symbiotic relationship. The organization One Step at a Time (Benedetto, n.d.) affirms that selfesteem involves relevant judgments, such as likes, dislikes, and associated emotions. Self-esteem is a need to enhance, protect, repair, and defend the self; it can also significantly influence personal behavior. Individuals with healthy self-esteem operate more effectively in everyday life (www.self-esteem-international.org).

People with low self-esteem feel that their everyday performance is not significant; they often develop feelings of inferiority and worthlessness. Characteristics found in the profile of individuals with unhealthy self-esteem include avoidance of challenging situations and self exposure, fear of failure, lack of effort, adjustment problems, defensiveness, insecurity, and loneliness (Gurney, 1987). Additionally, individuals with low self-esteem feel little or no sense of belonging, purpose, love, confidence, and respect for others.

Greenberg (1995) identifies the lack of social skills, identity, physical safety, and role models as causes of low self-esteem. These factors negatively affect the lives of children. A family that cares, supports, encourages, and loves their children is a positive influence in the child's life. The school environment can encourage students to develop 
and healthy self-esteem by providing activities in which they can make real decisions and contributions.

\section{Social Skills}

Socialization plays an important role in a child's life. Researchers define social skills as a set of abilities that enable interaction with others in ways that are acceptable or valued by society and are beneficial personally, mutually, or altruistically (Strain, Guralnick, \& Walker, 1986). Some have proposed three types of social skills: (1) taskrelated behaviors that include attendance, completion of tasks, adherence to rules, and independent work; (2) interpersonal behaviors, including acceptance of authority, conversational skill, cooperative actions, and playing; and (3) self-related behaviors, which embrace how to express feelings, ethical manners, and positive attitudes toward the self (Strain, Guralnick, \& Walker, 1986).

A socially skilled person can adapt well to his or her environment, avoiding verbal and physical conflict through communication with others (Matson, \& Ollendick, 1988). On the contrary, the socially unskilled individual often engages in behavioral problems such as fights, is unpopular with peers, and does not get along well with adults (Matson, \& Ollendick, 1988).

Researchers describe a child with poor social skills as one who does not follow the accepted rules of society, curses repeatedly, talks back to adults, argue with peers, and refuse to recngnize the right of others (Strain, Guralnick, \& Walker, 1986). Reinforcing social skills can help a child to develop a better understanding of how to build and maintain relationships, manage undesirable social behaviors, follow rules, and respect the rights and privileges of others. 
Music, Self-Esteem, Social Skills, and At-risk Students

Glenn (1992) believes that music is a powerful tool with which to reach out to atrisk youth and offer them a chance for hope and meaning in their lives. It can enlarge the aesthetic dimension of students' lives, especially those affected by a negative environment. Music participation can encourage self-expression and enhance feelings of self-worth. Duerksen and Darrow (1991) affirm that music educators are doing far more for students than just teaching music. The one-on-one or group relationship that happens in the music classroom allow teachers to influence students by providing a positive role model, teaching them to accomplish tasks in a constructive way, establishing and accomplishing realistic goals, and challenging their critical and creative thinking skills (Vlasek, 2006). A number of studies have dealt with the effectiveness of music as reinforcement for desirable non-music behaviors (Duerksen \& Darrow, 1991).

Music participation in performing, composing, or listening can promote a sense of gratification and accomplishment (Duerksen \& Darrow, 1991). These factors are major components of self-esteem and social skills. Because of the special nature and appeal of music, music educators can be uniquely effective in addressing the needs of at-risk students by creating personalized, structured experiences and a positive environment in which to benefit from them. Effective after-school programs provide at-risk students an opportunity to develop their social and interpersonal skills. As they socialize together outside the classroom, they cooperate with each other and spend more time on constructive, enriching activities that form healthy habits and attitudes (Huang, 2001). The Maryland Middle School Steering Committee Report (2008) suggests that instruction 
in dance, music, theater, and visual arts bolsters critical thinking and creative problemsolving; cultivates skills, discipline, flexibility, and innovation; seeds motivation, perseverance, and self-awareness; and fosters tolerance. The inclusion of the arts in programs designed to accommodate at-risk students meets the need to increase selfesteem and social skills.

\section{After-School Programs}

Participation in after-school programs can help children improve their academic performance, social skills, and self-confidence. Every day in the United States, more than 28 million school-aged children have parents who work outside the home (Otterbourg, 2000).. Many children return after the school day to an empty house, and consequently juvenile crime peaks between 3:00 p.m. and 9:00 p.m. (Otterbourg, 2000). After-school programs have been created in response to concerns about crime from worried parents and communities. The primary benefits school-aged children receive from after-school programs include safety, reduction of risk taking, and increased learning (Chung, 2000). Currently, government and private entities offer a wide variety of after-school programs in at-risk communities to meet the needs of children. Many after-school programs include the arts. Engagement in the arts can nurture the development of cognitive, social, and personal competencies. In How the Arts Can Enhance After-School Programs, Otterbourg (2000) lists specific benefits that emerge from arts participation. Benefits of arts education include increased critical thinking, interpretation and understanding of complex symbols, and enhanced imagination and judgment.

Participation in the arts also develops the motivation, skill, and discipline to contribute towards a group effort. Arts activities promote cooperation through a shared 
purpose, such as performing in a play or music concert. These positive environmental and social experiences channel student energies into constructive activities that enhance their development into responsible and productive adults and citizens (Huang, 2001).

High-quality programs help students develop academic and social skills, and foster positive attitudes towards community and school. They can also improve work habits, school attendance, attitudes towards the self, and dropout rates (Madura, 2006). The inclusion of arts in after-school programs provides academic enrichment, social skill building, leadership experiences, a sense of unity, and cooperation. This increases selfworth and a sense of mastery that can enable students to be resilient in difficult times. 


\section{CHAPTER 3}

\section{METHOD}

\section{Design and Procedure}

The study used a one-group, pre-test-post-test design. The one-group pre-test-post test design involved administering a pre-test that measured the dependent variable, implementing the experimental treatment, and administering a post-test that measured the dependent variable again (Gall, Gall, \& Borg, 2007). Participants in POSJU were examined during a period of twelve weeks from March to May 2009. The program structure did not change during the examination term. During the evaluation, students participated in their music lessons, rehearsals, and recitals as regularly scheduled.

To assess self-esteem and social skills, participants completed the Rosenberg's Self-Esteem Rating Scale (RSES) and a Social Skills Competence Checklist (SSCC) at the beginning and end of the twelve-week examination period. The Rosenberg SelfEsteem Scale is perhaps the most widely used self-esteem measure in social science research (http://www.bsos.umd.edu/socy/Research/rosenberg.htm). Generally, the scale has high reliability; test-retest correlations are typically in the range of .82 to .88 (University of Maryland, n.d.). This scale consists of ten Likert-type items answered on a four-point scale from "strongly agree" to "strongly disagree." The Social Skills Competence Checklist was adapted from the Illinois Early Learning Children Competence Checklist. The Social Skills Competence Checklist is a 27 -item checklist intended to assess children's social capability. Authors describe it as a way to help teachers observe, understand, and support children whose social skills are still forming (Illinois State Department of Education, n.d.). Finally, parents completed a questionnaire 
report $(\mathrm{PQR})$ related to their family, child, and views of the program at the beginning and at the end of the examination period.

POSJU music teachers assessed students using the Teacher Student Response (TSR) to measure outward behaviors. Both of these surveys, the Parent Questionnaire Report and the Teacher Student Report, are a modification of the After-School Activities survey used for the longitudinal study of Promising After-School Programs in 2005. Pre- and post-test scores for all surveys were examined by using Analysis of Variance (ANOVA). This procedure determined whether the difference between the mean scores of two or more groups on a dependent variable was statistically significant (Gall, Gall, \& Borg, 2007). Descriptive statistics were gleaned from the data as well. 


\section{CHAPTER 4}

\section{RESULTS}

Overview

The objective of this study was to assess POSJU participants' self-esteem and social skills after participating in the after-school music program. Additionally, community views of POSJU were obtained from the participants' relatives.

The evaluation took place over a period of twelve weeks in an after-school program in San Juan, Puerto Rico. Forty students and their parents participated in pre-test and post-test examination; however, only $\mathrm{N}=38$ students completed both the Rosenberg Self-Esteem survey (RSES) and the Social Skills Competence Checklist (SSCC). The final sample size consisted of 20 males and 18 females. In addition, parents $(\mathrm{N}=38)$ completed the Parents Report Questionnaire (PRQ) and six teachers completed the Teacher Student Report (TSR) for each participant before and after the evaluation period. Results

Self-Esteem. To assess self-esteem, student participants rated their level of agreement with ten statements concerning self-esteem using the RSES. The Wilcoxon Match-Pairs Signed-Ranks Test was used to compare pre-test and post-test due to a skew in survey results. Data analysis showed no significant differences between pretest and post-test. Overall, participant responses indicated positive attitudes towards selfesteem. Pre-test and post-test means are in Table 1. 
Table 1.

Rosenberg Self-Esteem Scale Means

Statement

Pre-Test

Post-Test

I feel that I'm a person of worth, at least on an equal par with others.

I feel that I have a number of good qualities

2.93

2.96

All in all, I am inclined to feel that I'm a failure.*

I am able to do things as well as most other people.

I feel I do not have much to be proud of.*

I take a positive attitude toward myself.

On the whole, I am satisfied with myself.

I wish I could have more respect for myself.

I certainly feel useless at times.*

At times I think that I am no good at all.*

Note. The answers were given on a rating scale of 1 to 4 , with 1 being "Strongly disagree" and 4 being "Strongly agree." *Negative statement towards the self

Social Skills. Student participants completed the Social Skills Competence Check list (SSCC) to assess social skills. In this evaluation, three different skills were measured: individual traits, social skills, and peer relationships. Pre- and post-test scores were compared using Wilcoxon Matched-pairs Signed Rank Test. No significant differences were found on either measure.

For additional information, teachers evaluated all participants using the Teacher Student Report (TSR). The Wilcoxon Matched-pairs Signed Rank Test revealed significant differences in 14 statements on the TSR (see Table 2.). 
Table 2.

Teacher Evaluations of POSJU Participants

Demonstrated Behaviors

Z

$p$

Working Habits

Completes work promptly

2.87

.004

Follows program procedures

2.00

.046

Works neatly and carefully

2.77

.005

Social Skills with Peers

Understands others' feelings

3.15

.002

Is socially aware of what is happening in a situation

2.83

.005

Refrains from over-impulsive responding

2.74

.006

Generates many solutions to interpersonal problems

3.37

.001

Behavior with other Students

Seems concerned when other students are distressed

Is kind towards students

Listen to students

Argues with students

Task Persistence

This student handles unexpected problems very well

This student can depend on himself/herself

This student gives up easily

2.16

.030

Wilcoxon signed rank test $p<0.05$

Parent Views'. Important information concerning the student and POSJU afterschool program was collected from parents through a Parent Questionnaire Report (PQR). Data analysis revealed that $87.5 \%$ of respondents were single mothers. 
Parents rated their level of agreement with statements concerning their child's social behavior. The Wilcoxon Signed Rank Test showed no significant differences between pre-test and post-test. Parents also shared information about their child's involvement in school and community activities. Results showed that students were not involved in other extra-curricular activities other than POSJU and religious classes or services. Additionally, $70 \%$ of POSJU students attended the program more than 4 days a week and $32.3 \%$ participated in religious activities in their communities.

Parents' views towards POSJU after-school program were also gathered through PQR. The Wilcoxon Signed Rank Test showed no significant differences between pretest and post-test. Overall, parents' responses towards the program were positive showing satisfaction with POSJU (see Table 3). 
Table 3.

Parents views towards POSJU

\begin{tabular}{|c|c|c|c|c|c|}
\hline Statement & $\begin{array}{l}\text { Strongly } \\
\text { disagree }\end{array}$ & Disagree & $\begin{array}{l}\text { Neither } \\
\text { agree } \\
\text { nor } \\
\text { disagree }\end{array}$ & Agree & $\begin{array}{l}\text { Strongly } \\
\text { agree }\end{array}$ \\
\hline The program meets my child's needs & 0 & 0 & 0 & 0 & 75 \\
\hline $\begin{array}{l}\text { My child complains about not getting } \\
\text { enough time to him/herself }\end{array}$ & 46.9 & 0 & 0 & 0 & 0 \\
\hline $\begin{array}{l}\text { My child is given enough say in } \\
\text { choosing activities }\end{array}$ & 0 & 0 & 0 & 0 & 54.8 \\
\hline $\begin{array}{l}\text { There are enough different activities } \\
\text { offered that my child can choose what } \\
\text { to do }\end{array}$ & 0 & 0 & 0 & 0 & 54.8 \\
\hline $\begin{array}{l}\text { I am a satisfied with the qualities of } \\
\text { activities my child has been involved } \\
\text { in this year }\end{array}$ & 0 & 0 & 0 & 0 & 83.9 \\
\hline My child likes going to POSJU & 0 & 0 & 0 & 0 & 81.3 \\
\hline The kids at POSJU are good kids & 0 & 0 & 0 & 0 & 71.9 \\
\hline $\begin{array}{l}\text { The staff at POSJU are critical of my } \\
\text { child }\end{array}$ & 0 & 0 & 0 & 0 & 84.4 \\
\hline POSJU is a safe place to be & 0 & 0 & 0 & 0 & 68.8 \\
\hline $\begin{array}{l}\text { The staff is fair in disciplining my } \\
\text { child and enforcing rules }\end{array}$ & 0 & 0 & 0 & 0 & 90.6 \\
\hline $\begin{array}{l}\text { I worry when my child is with this } \\
\text { group of kids }\end{array}$ & 71.9 & 0 & 0 & 0 & 0 \\
\hline The staff tell me how my child is doing & 0 & 0 & 0 & 0 & 65.6 \\
\hline $\begin{array}{l}\text { My child has time to relax and play at } \\
\text { POSJU }\end{array}$ & 0 & 0 & 0 & 0 & 53.1 \\
\hline $\begin{array}{l}\text { The relations with the staff and my } \\
\text { child are positive }\end{array}$ & 0 & 0 & 0 & 0 & 90.6 \\
\hline $\begin{array}{l}\text { POSJU is a good environment for my } \\
\text { child to build friendships }\end{array}$ & 0 & 0 & 0 & 0 & 75 \\
\hline $\begin{array}{l}\text { I'm satistied with PUSJU's hours of } \\
\text { operation }\end{array}$ & 0 & 0 & 0 & 0 & 75 \\
\hline POSJU is in a convenient location & 0 & 0 & 0 & 0 & 81.3 \\
\hline $\begin{array}{l}\text { Some of the kids are a bad influence } \\
\text { on my child }\end{array}$ & 71 & 0 & 0 & 0 & 5 \\
\hline Overall, I'm satisfied with POSJU & 0 & 0 & 0 & 0 & 78.1 \\
\hline
\end{tabular}




\section{CHAPTER 5}

\section{DISCUSSION}

\section{Research Objectives}

The first objective of the study was to evaluate the extent to which participation in POSJU helps to enhance self-esteem in at-risk students. The results indicated minimal, statistically insignificant differences between the pre-test and post-test measurement points. This finding was congruent with Wright, John, Ellenbogen, Offord, Duku, and William (2006), who found improvement in emotional well-being without a congruent increase in self-esteem. A similar study by Michel and Martin (1973) revealed the same outcomes-a small, non-significant difference in self-esteem.

The second objective of the study was to determine if the participation in POSJU enhanced social-skills among student participants. Student views towards their own social skills were unchanged. There was, however, a significant difference between corresponding pre- and post-test items among the 18 statements on the Teacher Student Report regarding social skills. These findings contribute to the assertion that participation in music activities does help to enhance social skills. Wright et al. (2006) have suggested that structured art programs provide an opportunity for youth to develop important communication, cooperation, conflict resolution, and teamwork skills.

The third objective of the study concerned the parent views of POSJU. Parents indicated that students benefited from POSJU by having a structured after-school program and by having an adequately supervised environment. Another study found similar conclusions related to structured after-school programs. Their findings suggest that well-designed youth center programs produce positive outcomes in participants 
(Nicholson, Collins, \& Holmer, 2004). Another positive benefit of POSJU is that it prompted students to develop innate abilities and talents.

\section{Study Limitations}

This study has several limitations to acknowledge. First, the validation of the selfesteem measure needs to be addressed. While the Rosenberg scale is a well-accepted selfesteem measure in social science, and multiple studies have investigated its reliability, age plays a major role in the validity of the results. The RSES is designed to be used with adults; therefore when used with children and teenagers it is difficult to know whether the change in scores is meaningful. In addition, the fact that the RSES is not targeted for the Hispanic population should be taken into account.

Another limitation is the length of the experiment. This study was conducted over twelve weeks, limiting the opportunities for repeated observations and for longitudinal testing that would permit tracking of behavioral changes over time. Additionally, the sample size of participants and the size of the participants were rather small. The participants in this study were not randomly selected, which also limits the generalization of the results and the intended outcomes for the targeted population.

\section{Future Suggestions}

To understand the effect of participation in after-school programs on students' self-esteem and social skills, further research must be done. This research should focus on identifying a more targeted population of at-risk students with an increased size of the sample to allow for a wider distribution of the obtained scores. It is imperative that key characteristics of the group are identified, as well as the external factors that influence the participant's experience. A new instrument should be developed to target the Hispanic 
population to obtain information about at-risk students' living conditions, school, and community.

Comparing new students to previously enrolled students could help significantly identify or isolate information related to the period of participation in the program. The data collected by comparing new participants' answers to those of already existing participants could also yield findings valuable to this study.

Directed measurement instruments specifically designed for the Hispanic teenage population and music programs in at-risk communities should be developed. With new instruments, accurate data could be gathered to demonstrate better understanding of Hispanic at-risk students and their particular cultural complexities and needs.

Finally, a longitudinal study could provide more information. With a short observation period, the power to obtain statistically significant information is restricted. The implementation of a longitudinal analysis with the suggestions already mentioned should make it possible to treat the targeted population effectively and successfully track students' emotional development in relation to their self-esteem. 


\section{REFERENCES}

Benedetto, G. (n.d.). Self-esteem. Retrieved October 24, 2008, from http://www.onestepatatime.com/lowselfesteemhelp.asp

Chung, A. M. (2000). After-school programs: keeping children safe and smart. Washington DC: US Department of Education, \& Partnership for Family Involvement in Education. Retrieved Nov 28, 2008 from www.ed.gov/pubs/afterschool/afterschool.pdf

Coopersmith, S. (1967). The antecedents of self-esteem. San Francisco, CA: Consulting Physchologists Pub.

Donnelly, M. (1987). At-risk students. University of Oregon, OR: ERIC Clearinghouse on Educational Management. (ERIC Document Reproduction Service No. ED292172)

Dougherty, J. (1990). Effective programs for at-risk adolescents. Bloomington, IN: Phi Delta Kappa Educational Foundation. (ERIC Document Reproduction Service No. 324572)

Duerksen, G. L., \& Darrow, A. (1991). Music class for the at-risk: A music therapist's perspective [special issue]. Music Educators Journal, 78(3)46-49.

Durian, G., \& Butler, J. (1987). Effective schooling practices and at-risk youth: What the research shows. Retrieved November 3, 2007, from http://www.nwrel.org/comm/hot.html

Gall, M., Gall, J., \& Borg, W. (2007). Educational research: An introduction ( $8^{\text {th }}$ ed.). Pearson Education, Inc.

Glenn, K. (1992). The many benefits of music education: Now and in the future. National Association of Secondary School Principals, 76(1)1-4.

Greenberg, R. (1995). Self-esteem enhancement through adult role model intervention. (ERIC Document Reproduction Service No. 391581)

Gurney, P. (1987). Self-esteem enhancement in children: A review of research findings. Educational Research, 29(2), 130-136. 
Hall, G., Yohalem, N., Tolman, J., \& Wilson, A. (2003). How afterschool programs can most effectively promote positive youth development as a support to academic achievement: A report commissioned by the Boston after-school for all partnership. Retrieved November 3, 2007, from http://www.noist.org /WCW3.pdf,(2007)

Huang, D. (2001). An after-school evaluation system for middle and high school programs. National Association of Secondary School Principals, 85(45), 45-61.

Illinois State Board of Education. (n.d.). Resources on early learning: Children's social competence checklist. Retrieved February, 3, 2009, from: http://illinoisearlylearning.org/tipsheets/checklist.htm

Johnston, H., Collins, C., \& Holmer, H. (2004). Youth as people: The protective aspects of youth development in after-school settings. The ANNALS of the American Academy of Political and Social Science, 591(55), 55-71.

Madura, P. (2006). The development of an after-school music program for at-risk children: Student musical preferences and pre-service teacher reflections. International Journal of Music Education, 24(1). 85-96.

Maryland State Department of Education. (2008). The critical middle: A reason for hope. Baltimore, MD: Maryland State Department of Education. (ERIC Document Reproduction Service No. ED 502204)

Matson, J. \& Ollendick, T. (1988). Enhancing children's social skills: Assessment and training (1 st ed.). New York: Pergamon Press.

Michel, D., \& Martin, D. (1973). Music and self-esteem: Disadvantage problem boys in all black elementary school. Journal of Research in Music Education, 21(1), 8084.

Otterbourg, S. D. (2000). How the arts can enhance after-school programs. Washington, DC: National Endowment for the Arts; \& Washington, DC: Partnership for Family Involvement in Education. (ERIC Document Reproduction Service No. ED446829)

Policy Studies Associates, Inc. (2005). Study of after-school activities Survey. Retrieved January, 15, 2009, from http://www.afterschoolresources.org/directory/research_evaluation/instruments.ht $\mathrm{ml}$

Reasoner, R. (n.d.). International council for self-esteem. Position paper on the Meaning of self-esteem. Retrieved November 6, 2008, from http://self-esteeminternational.org/ARTICLES/meaning.htm 
Robinson, N. (2004). Who is "at-risk" in the music classroom? Music Educators Journal, 90(4), 38-43.

Shumow, L. (2001). Academic effects of after-school programs. Champaign, IL: ERIC Clearinghouse on Elementary and Early Childhood Education. (ERIC Document Reproduction Service No. ED 458010)

Strain, P., Guralnick, M., \& Walker, H. (1986). Children's social behavior:

Development, assessment, and modification ( $1^{\text {st }}$ ed. $)$. Florida: Academic Press Inc.

Taylor, A., Barry, N., \& Walls, K. (1997). Music and students at-risk: Creative solutions for a national dilemma. Reston, VA: Music Educators National Conference.

Universidad de Puerto Rico. (n.d). Datos y estadisticas de Puerto Rico y sus municipios. Retrieved October 27, 2008 from http://www.tendenciaspr.com/Salud/Drogas_y_Alcohol/Tablas_Drogas_y_Alcoh ol/04_Evo_por_edad_ultima_vez.htm

University of Maryland. (n.d.). The Rosenberg self-esteem scale. Retrieved April 9, 2009, from the University of Maryland Sociology Department Web site:

http://www.bsos.umd.edu/socy/Research/rosenberg.htm

Vlasek, D. (2006). Forum focus: Arts awareness and advocacy, Are we doing enough? American Music Teacher, 56(1), 78-79.

Wright, R., John, L., Ellenboge, S., Offord, D., Duku, E., \& William, R. (2006).Effect of a structure arts program on the psychological functioning of youth from lowincome communities: Findings from a Canadian longitudinal study. The Journal of Early Adolecence, 26(186), 186-205. 
APPENDIX 1

ASSENT AND CONSENT LETTERS 


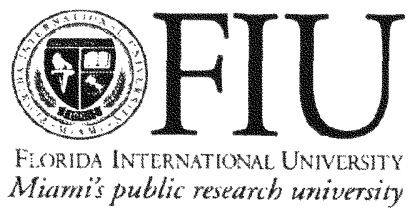

\section{CONSENT/ASSENT TO PARTICIPATE IN A RESEARCH STUDY}

\section{Title: The Effects of After-School Music Programs on At-Risk Students Self-Esteem and Social Skills in San Juan, Puerto Rico.}

My name is Carmen Collazo, I'm a graduate student from Florida International University. I'm doing a research about after-school music programs and its effects on self-esteem and social skills. The study will take place at the Felipe Gutierrez y Espinoza school one of the POSJU center.

If both of you decided to be a part of the study we will tell you what day and time to come to the Felipe Gutierrez y Espinoza school. You will be asked to complete a written survey. Someone in the school will explain and help you to complete the survey. You will only need to answer the questions. You as a parent will be asked to answer general questions about: 1) your child; 2) your family constitution; 3) schooling; 4) your opinion about POSJU. Your child will be asked to complete a: (1) Self-Esteem rating scale; and a (2) Social Competence check list both at the beginning of the study and then again in 3 months.

There are no known risks to you and your child as a participant in the study greater than if you completed a survey or took a test in class. Some of the questions may be personal to you. You may skip any questions that you choose. If you get upset or feel uncomfortable you can ask to take a break. All your answers will be kept private. There may be no direct benefit to you by being in the study. However, this research will give us information about participants at POSJU. At the end of the study, we will have a general forum that will be open to the administrators and teachers from the school, your parents, students and the community. We hope to encourage conversation with the forum.

There is no cost to you to be in the study. All data will be identified by random numbers. All data in this research is private and will not be shared with anyone not directly related to the study unless required by law. The results will be presented as a group in all publications, at the general forum and conferences. You may ask questions about the study at any time. You or your parent may request that you be removed from the study at any time and no one will be upset with you.

If either of you feel that you were mistreated or you have questions about your participation as a volunteer in this research study you may contact Dr. Patricia Price, the Chairperson of the FIU Institutional Review Board at 305-348-2618 or 305-348-2494 or me at 954-830-1565.

If you have had all of your questions answered to your liking and you would like to be in the study sign below. 
If you have had all of your questions answered to your liking and you would like your child, to be in the study, sign below.

(Print Teen's name)

Signature of Parent

Date

I have explained the research procedure, subject rights and answered questions asked by the participant. I have offered him/her a copy of this informed consent form.

Signature of Witness

Date 


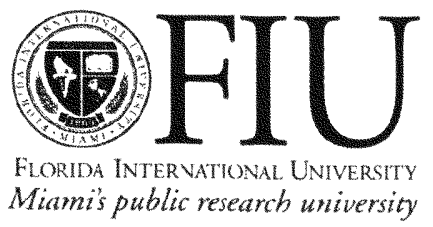

\section{CONSENTIMIENTO Y ASENTIMIENTO PARA PARTICIPAR EN UN ESTUDIO INVESTIGATIVO}

\section{Titulo: La Participación en Programas Extracurriculares de Música y el Efecto que Tiene Sobre la Autoestima y las Destrezas Sociales en Estudiantes en San Juan Puerto Rico.}

Mi nombre es Carmen Collazo, soy estudiante de la Universidad Internacional de la Florida. Estoy haciendo una investigación sobre los programas extracurriculares de música y el efecto que tiene en la autoestima y las destrezas sociales en los niños. La investigación se llevara a cabo en la escuela Felipe Gutiérrez y Espinoza en la cual se encuentra uno de los centros POSJU.

Si usted y su hijo deciden ser parte del estudio nosotros les diremos el día y la hora en la que deberá presentarse en la escuela Felipe Gutiérrez y Espinoza. Se le pedirá a usted que complete un cuestionario. Alguien en la escuela le explicara y le ayudara a completar el cuestionario. Solo necesitara contestar varias preguntas que se relacionan a su 1) hijo;2) familia; 3) escuela; y 4) su opinión sobre POSJU. Su hijo completara un cuestionario sobre 1) autoestima; y 2) destrezas sociales los cuales volverá a completar al final de la investigación. No hay ningún tipo de riesgos relacionados a la investigación. Algunas preguntas pueden ser de carácter personal. Puedes omitir cualquier pregunta que te haga sentir incomodo (a).

Si te sientes molesto durante el proceso puedes tomarte un receso. Todas tus contestaciones serán completamente privadas. Tal vez no haya un beneficio directo hacia tu persona por participar en el estudio pero tu ayuda nos dará información importante sobre los participantes del programa POSJU. Al final de la investigación tendremos un foro abierto para los participantes, maestros y personal del programa.

La participación en el estudio es libre de costo. Toda la data recolectada será identificada por números al azar. Toda la información será estrictamente privada y no se compartirá con nadie que no esté directamente relacionado al estudio a menos que la ley lo requiera. Los resultados serán presentados como grupo en todas las publicaciones, foros $\mathrm{y} / \mathrm{o}$ conferencias. Puedes hacer preguntas sobre el estudio en cualquier momento. Usted y su hijo pueden ser removidos del estudio en cualquier momento si así lo desean, nadie se molestara con ninguno de ustedes. 
$\mathrm{Si}$ alguno de los dos siente que ha sido maltratado o tiene alguna pregunta sobre su participación como voluntario en la investigación puede contactar a la Dra. Patricia Price, directora del FIU Institutional Review Board al 305-348-2618 o al 305-348-2494 o a mí al 954-830-1565.

Si tienes todas tus dudas aclaradas sobre el estudio y quisieras participar, firma abajo.

Tu firma también indica que permitirás a tu hijo (a)

participar en el estudio.

(Nombre del estudiante)

Firma del participante

Fecha

He explicado el procedimiento del estudio, derechos del participante y he contestado las preguntas hechas por parte del participante. He ofrecido al participante una copia de la forma de consentimiento.

Firma del testigo

Fecha 


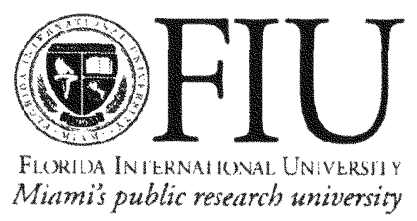

\section{CONSENT TO PARTICIPATE IN A RESEARCH STUDY}

\section{Title: The Effects of After-School Music Programs on At-Risk Students Self-Esteem and Social Skills in San Juan, Puerto Rico.}

You are being asked to participate in a research study. The investigator of this study is Carmen Collazo and she is a student at FIU. The study will include about 30 people who are participants at the Programa Orquestas Sinfonicas Juveniles. Your participation will require some of your time while participating as a mentor at POSJU program. We are looking at the relationship between participation in POSJU and the possible effects on students' self-esteem and social skills.

You will be asked to complete a teacher student report every monthly for a period of three months. Someone in the school will explain and help you on how to complete the reports. You will only need to answer the questions. You will be asked to answer general questions about the students'; 1) work habits; 2) social skills with peers; 3) behaviors; and, 4) task persistence.

We do not expect any harm to you by being in the study. There is no cost or payment to you as a subject. You will not get any direct benefit from being in the study. However, your help will give us information about participants at POSJU.

All data collected is private and will not be shared with anyone unless required by law. We will present the research results as a group. You may ask questions about the study at any time. If you choose not to participate no one will be upset with you.

If you would like more information about this research after you are done, you can contact Dr. Kerstetter or me at 954-830-1565. If you feel that you were mistreated or would like to talk with someone about your rights as a volunteer in this research study you may contact Dr. Patricia Price, the Chairperson of the FIU Institutional Review Board at $305-348-2618$ or $305-348-2494$. 
Your signature below indicates that all questions have been answered to your liking. You are aware of your rights and you would like to be in the study.

Signature of Participant

Printed Name

Date

I have explained the research procedure, subject rights and answered questions asked by the participant. I have offered him/her a copy of this informed consent form.

Signature of Witness

Date 


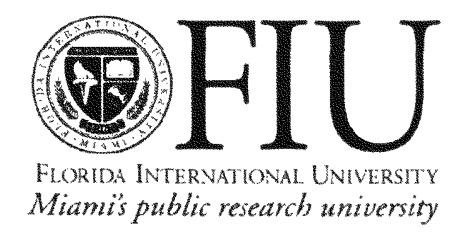

\section{CONSENTIMIENTO PARA PARTICIPAR EN UN ESTUDIO INVESTIGATIVO}

\section{Titulo: La participación en Programas Extracurriculares de Música y el Efecto que Tiene Sobre la Autoestima y las Destrezas Sociales en Estudiantes en San Juan Puerto Rico.}

Mi nombre es Carmen Collazo y soy estudiante de la Universidad Internacional de la Florida. La presente es para solicitar su participación en un estudio investigativo. El estudio incluirá aproximadamente 30 estudiantes participantes en el programa Orquestas Sinfónicas Juveniles. La investigación trata sobre los programas extracurriculares de música y el efecto que tiene en la autoestima y las destrezas sociales en los niños. Tu participación requerirá parte de su tiempo mientras participas como maestro y/o tutor en el programa POSJU.

Si decides ser parte de la investigación nosotros le diremos el día y la hora en la cual deberá presentarse en la escuela Felipe Gutiérrez y Espinoza. Usted deberá completar unos reportes mensuales sobre el estudiante por un periodo de tres meses. Alguien en la escuela le explicara y le ayudara a como completar los reportes. Usted solo contestara unas preguntas generales sobre: 1) los hábitos de estudio del estudiante; 2) destrezas sociales con los compañeros; 3 ) comportamientos; y 4) persistencia en las tareas.

No hay ningún tipo de riesgos relacionados a la investigación. La participación en el estudio es libre de costo. Tal vez no haya un beneficio directo hacia tu persona por participar en el estudio pero tu ayuda nos dará información importante sobre los participantes del programa POSJU.

Toda la información será estrictamente privada y no se compartirá con nadie que no esté directamente relacionado al estudio a menos que la ley lo requiera. Los resultados serán presentados como grupo en todas las publicaciones, foros y/o conferencias. Puedes hacer preguntas sobre el estudio en cualquier momento. Puedes ser removido del estudio si así lo deseas, nadie se molestara contigo.

Si sientes que has sido maltratado o tienes alguna pregunta sobre su participación como voluntario en la investigación puede contactar a la Dra. Patricia Price, directora del FIU Institutional Review Board al 305-348-2618 o al 305-348-2494.

Florida International University University Park, Miami, Florida 33199 
Si tienes todas tus dudas aclaradas sobre el estudio y quisieras participar, firma abajo.

Firma del participante

Fecha

He explicado el procedimiento del estudio, derechos del participante y he contestado las preguntas hechas por parte del participante. He ofrecido al participante una copia de la forma de consentimiento.

Firma del testigo

Fecha 
APPENDIX 2

PARENT QUESTIONAIRRE 
DATE:

\section{Please answer the following questions:}

1. What is your relationship to the student in POSJU? (Circle one)

1. Mother/Stepmother

2. Father/ Stepfather

3. Grandmother

4. Grandfather

5. Aunt

6. Uncle

7. Other adult (Specify:

2. Do you live with the child?

1. Yes

2. No

3. Is the student (circle one)

1. Male

2. Female

4. Circle each person who lives in this child's house. (Circle all that apply)

1. Mother/Stepmother/Father's partner

2. Father/Stepfather/Mother's partner

3. Grandmother

4. Grandfather

5. Aunt

6. Uncle

7. Other adults (Specify relationship:

8. The child's sisters, brothers, or cousins (circle how many): 123456 more than 6

5 . How much total income, before taxes, did everyone in this child's household receive in 2008 ? Please add up all the money adults received in 2008 and circle the number that is nearest to the correct income range. (Circle one)

1. $\$ 0-\$ 4,999$

2. $\$ 5,000-\$ 7,999$

3. $\$ 8,000-\$ 10,999$

4. $\$ 11,000-\$ 14,999$

5. $\$ 15,000-\$ 19,999$

6. $\$ 20,000-\$ 24,999$
7. $\$ 25,000-\$ 29,999$

8. $\$ 30,000-\$ 39,999$

9. $\$ 40,000-\$ 49,999$

10. $\$ 50,000-\$ 59,999$

11. $\$ 60,000$ or more 
II. For the next set of items, circle the numbers that best describe how often your child does each BEHAVIOR.

\begin{tabular}{|l|c|c|c|c|c|}
\hline My child.... & $\begin{array}{c}\text { Hardly } \\
\text { ever } \\
\%\end{array}$ & $\begin{array}{c}\text { Not } \\
\text { usually } \\
\%\end{array}$ & $\begin{array}{c}\text { In- } \\
\text { between } \\
\%\end{array}$ & $\begin{array}{c}\text { Usually } \\
\%\end{array}$ & $\begin{array}{c}\text { Almost } \\
\text { always } \\
\%\end{array}$ \\
\hline Teases others & 1 & 2 & 3 & 4 & 5 \\
\hline Is easily distracted & 1 & 2 & 3 & 4 & 5 \\
\hline Is popular & 1 & 2 & 3 & 4 & 5 \\
\hline Talks back to adults & 1 & 2 & 3 & 4 & 5 \\
\hline Is happy & 1 & 2 & 3 & 4 & 5 \\
\hline Shares with others & 1 & 2 & 3 & 4 & 5 \\
\hline Sown problems on his or her & 1 & 2 & 3 & 4 & 5 \\
\hline Threatens others & 1 & 2 & 3 & 4 & 5 \\
\hline Is alert & 1 & 2 & 3 & 4 & 5 \\
\hline
\end{tabular}




\begin{tabular}{|c|c|c|c|c|c|}
\hline Hits other kids & 1 & 2 & 3 & 4 & 5 \\
\hline Ignores other people & 1 & 2 & 3 & 4 & 5 \\
\hline Respects other people's things & 1 & 2 & 3 & 4 & 5 \\
\hline Is talkative around others & 1 & 2 & 3 & 4 & 5 \\
\hline Is unhappy & 1 & 2 & 3 & 4 & 5 \\
\hline $\begin{array}{l}\text { Keeps trying when playing } \\
\text { games that are hard }\end{array}$ & 1 & 2 & 3 & 4 & 5 \\
\hline Takes turns & 1 & 2 & 3 & 4 & 5 \\
\hline Fights with others & 1 & 2 & 3 & 4 & 5 \\
\hline Is loving & 1 & 2 & 3 & 4 & 5 \\
\hline Tattles on others & 1 & 2 & 3 & 4 & 5 \\
\hline Is shy & 1 & 2 & 3 & 4 & 5 \\
\hline $\begin{array}{l}\text { Is slow at learning new subjects } \\
\text { at school }\end{array}$ & 1 & 2 & 3 & 4 & 5 \\
\hline $\begin{array}{l}\text { Quits working on a job when } \\
\text { problems come up }\end{array}$ & 1 & 2 & 3 & 4 & 5 \\
\hline Is organized & 1 & 2 & 3 & 4 & 5 \\
\hline Is good at sports & 1 & 2 & 3 & 4 & 5 \\
\hline
\end{tabular}




\begin{tabular}{|l|l|l|l|l|l|}
\hline $\begin{array}{l}\text { Likes doing things with friends } \\
\text { instead of family }\end{array}$ & 1 & 2 & 3 & 4 & 5 \\
\hline Is hard to discipline & 1 & 2 & 3 & 4 & 5 \\
\hline Wants to do well in school & 1 & 2 & 3 & 4 & 5 \\
\hline Disobeys adults & 1 & 2 & 3 & 4 & 5 \\
\hline $\begin{array}{l}\text { Works well without the help of } \\
\text { adults }\end{array}$ & 1 & 2 & 3 & 4 & 5 \\
\hline
\end{tabular}

III. Circle the number that tells how often your child has done the following activities this school year.

\begin{tabular}{|l|c|c|c|c|c|}
\hline $\begin{array}{l}\text { How often has your child done } \\
\text { each type of activity listed } \\
\text { below? }\end{array}$ & $\begin{array}{c}\text { Not at } \\
\text { all }\end{array}$ & $\begin{array}{c}\text { Once or } \\
\text { twice }\end{array}$ & $\begin{array}{c}\text { About } \\
\text { once a } \\
\text { week }\end{array}$ & $\begin{array}{c}\text { 2 or 3 } \\
\text { days a } \\
\text { week }\end{array}$ & $\begin{array}{c}4 \text { or } \\
\text { more } \\
\text { days a } \\
\text { week }\end{array}$ \\
\hline Gone to POSJU after-school & 1 & 2 & 3 & 4 & 5 \\
\hline $\begin{array}{l}\text { Taken extra reading or math } \\
\text { classes after school }\end{array}$ & 1 & 2 & 3 & 4 & 5 \\
\hline $\begin{array}{l}\text { Take lesson in art, dance, sports } \\
\text { or some other activity after- } \\
\text { school }\end{array}$ & 1 & 2 & 3 & 4 & 5 \\
\hline $\begin{array}{l}\text { Gone to religious classes (e.g., } \\
\text { Sunday school, catechism) or } \\
\text { services (e.g., mass) at your } \\
\text { church, mosque, or temple }\end{array}$ & 1 & 2 & 3 & 4 & 5 \\
\hline $\begin{array}{l}\text { Played on an organized sports } \\
\text { team (e.g., soccer or basketball } \\
\text { team) after school }\end{array}$ & 1 & 2 & 3 & 4 & 5 \\
\hline $\begin{array}{l}\text { Gone to a different club or } \\
\text { organization after school that we } \\
\text { didn't already ask you about }\end{array}$ & 1 & 2 & 3 & 4 & 5 \\
\hline $\begin{array}{l}\text { Been home alone after school } \\
\text { without an adult there }\end{array}$ & 1 & 2 & 3 & 4 & 5 \\
\hline $\begin{array}{l}\text { Taken care of a sister or brother } \\
\text { after school without an adult } \\
\text { there }\end{array}$ & 1 & 2 & 3 & 4 & 5 \\
\hline
\end{tabular}


IV. During the school year, how often has your child gone to POSJU after-school program? (Circle one)

\begin{tabular}{|l|l|}
\hline Not at all & 0 \\
\hline Once or twice & 1 \\
\hline About once a week & 2 \\
\hline $2-3$ days a week & 3 \\
\hline 4 or more days a week & 4 \\
\hline
\end{tabular}

V. For each statement, circle the number that best describes what you think about POSJU?

\begin{tabular}{|l|c|c|c|c|c|}
\hline & $\begin{array}{c}\text { Strongl } \\
\text { y } \\
\text { disagree }\end{array}$ & $\begin{array}{c}\text { Disagre } \\
\mathrm{e}\end{array}$ & $\begin{array}{c}\text { Neither } \\
\text { agree } \\
\text { nor } \\
\text { disagree }\end{array}$ & Agree & $\begin{array}{c}\text { Strongl } \\
\text { y agree }\end{array}$ \\
\hline $\begin{array}{l}\text { The program meets my child's } \\
\text { needs }\end{array}$ & 1 & 2 & 3 & 4 & 5 \\
\hline $\begin{array}{l}\text { My child complains about not } \\
\text { getting enough time to } \\
\text { him/herself }\end{array}$ & 1 & 2 & 3 & 4 & 5 \\
\hline $\begin{array}{l}\text { My child is given enough say in } \\
\text { choosing activities }\end{array}$ & 1 & 2 & 3 & 4 & 5 \\
\hline $\begin{array}{l}\text { There are enough different } \\
\text { activities offered that my child } \\
\text { can choose what to do }\end{array}$ & 1 & 2 & 3 & 4 & 5 \\
\hline $\begin{array}{l}\text { I am a satisfied with the } \\
\text { qualities of activities my child } \\
\text { has been involved in this year }\end{array}$ & 1 & 2 & 3 & 5 \\
\hline My child likes going to POSJU & 1 & & 3 & 5 & 5 \\
\hline
\end{tabular}




\begin{tabular}{|l|l|l|l|l|l|}
\hline $\begin{array}{l}\text { The kids at POSJU are good } \\
\text { kids }\end{array}$ & 1 & 2 & 3 & 4 & 5 \\
\hline $\begin{array}{l}\text { The staff at POSJU are critical } \\
\text { of my child }\end{array}$ & 1 & 2 & 3 & 4 & 5 \\
\hline $\begin{array}{l}\text { POSJU is a safe place to be } \\
\text { my child and enforcing rules }\end{array}$ & 1 & 2 & 3 & 4 & 5 \\
\hline $\begin{array}{l}\text { I worry when my child is with } \\
\text { this group of kids }\end{array}$ & 1 & 2 & 3 & 4 & 5 \\
\hline $\begin{array}{l}\text { The staff tell me how my child } \\
\text { is doing }\end{array}$ & 1 & 2 & 3 & 4 & 5 \\
\hline $\begin{array}{l}\text { Mos } \\
\text { my child are positive } \\
\text { play at POSJU }\end{array}$ & 1 & 2 & 3 & 4 & 5 \\
\hline $\begin{array}{l}\text { POSJU is a good environment } \\
\text { for my child to build friendships }\end{array}$ & 1 & 2 & 3 & 4 & 5 \\
\hline
\end{tabular}




\begin{tabular}{|l|c|c|c|c|c|}
\hline $\begin{array}{l}\text { Some of the kids are a bad } \\
\text { influence on my child }\end{array}$ & 1 & 2 & 3 & 4 & 5 \\
\hline $\begin{array}{l}\text { Overall, I'm satisfied with } \\
\text { POSJU }\end{array}$ & 1 & 2 & 3 & 4 & 5 \\
\hline
\end{tabular}


FECHA:

\section{Por favor conteste las siguientes preguntas:}

1. Cuál es su relación con el estudiante en POSJU? (Encierre en un círculo)

1. Madre/Madrastra

2. Padre/Padrastro

3. Abuela

4. Abuelo

5. Tía

6. Tío

7. Otro adulto (Especifique:

2. Vive usted con el niño (a)?

1. Sí

2. No

3. El estudiante es (encierre en un círculo)

1. Varón

2. Hembra

4. Dibuje un círculo alrededor de cada persona que vive en la casa con el niño (a). (Todos los que apliquen)

1. Madre/Madrastra/Compañera del padre

2. Padre/Padrastro/Compañero de la madre

3. Abuela

4. Abuelo

5. Tía

6. Tío

7. Otros adultos (Especifique la relación:

8. Hermanos (as), primos(as) del niño(a) (señale cuántos): 123456 más de 6

5. Cuál fue el ingreso económico, antes de declarar impuestos, que se recibió en total en la casa del niño en el año 2008? Por favor sume todo el dinero recibido por los adultos en el 2008 y dibuje un círculo alrededor del número que más se aproxime. (Encierre solo uno)

$1 . \$ 0-\$ 4,999$

11. $\$ 60,000$ o más

2. $\$ 5,000-\$ 7,999$

3. $\$ 8,000-\$ 10,999$

4. $\$ 11,000-\$ 14,999$

5. $\$ 15,000-\$ 19,999$

6. $\$ 20,000-\$ 24,999$

7. $\$ 25,000-\$ 29,999$

8. $\$ 30,000-\$ 39,999$

9. $\$ 40,000-\$ 49,999$

10. $\$ 50,000-\$ 59,999$ 
En la siguiente lista, encierre en un círculo el número que mejor describa con qué frecuencia su niño (a) tiene dicho COMPORTAMIENTO.

\begin{tabular}{|l|c|c|c|c|c|}
\hline \multicolumn{1}{|c|}{ Mi niño (a)... } & $\begin{array}{c}\text { Casi } \\
\text { nunca }\end{array}$ & $\begin{array}{c}\text { No } \\
\text { comun- } \\
\text { mente }\end{array}$ & $\begin{array}{c}\text { En } \\
\text { medio }\end{array}$ & $\begin{array}{c}\text { Comun- } \\
\text { mente }\end{array}$ & $\begin{array}{c}\text { Casi } \\
\text { siempre }\end{array}$ \\
\hline Molesta a los demás & 1 & 2 & 3 & 4 & 5 \\
\hline Se distrae fácilmente & 1 & 2 & 3 & 4 & 5 \\
\hline Es popular & 1 & 2 & 3 & 4 & 5 \\
\hline $\begin{array}{l}\text { Responde a los adultos cuando } \\
\text { no debe }\end{array}$ & 1 & 2 & 3 & 4 & 5 \\
\hline Es feliz & 1 & 2 & 3 & 4 & 5 \\
\hline $\begin{array}{l}\text { Comparte con los demás } \\
\text { mismo (a) }\end{array}$ & 1 & 2 & 3 & 4 & 5 \\
\hline $\begin{array}{l}\text { Escucha cuando los demás } \\
\text { hablan }\end{array}$ & 1 & 2 & 3 & 4 & 5 \\
\hline Esmenaza a otros & 1 & 2 & 3 & 4 & 5 \\
\hline Está alerta & 1 & 2 & 3 & 4 & 5 \\
\hline
\end{tabular}




\begin{tabular}{|c|c|c|c|c|c|}
\hline Golpea a otros niños & 1 & 2 & 3 & 4 & 5 \\
\hline Ignora a la gente & 1 & 2 & 3 & 4 & 5 \\
\hline Respeta las cosas ajenas & 1 & 2 & 3 & 4 & 5 \\
\hline Conversa con los demás & 1 & 2 & 3 & 4 & 5 \\
\hline No es feliz & 1 & 2 & 3 & 4 & 5 \\
\hline $\begin{array}{l}\text { En un juego dificil, lo sigue } \\
\text { intentando }\end{array}$ & 1 & 2 & 3 & 4 & 5 \\
\hline Toma turnos & 1 & 2 & 3 & 4 & 5 \\
\hline Pelea con los demás & 1 & 2 & 3 & 4 & 5 \\
\hline Es cariñoso & 1 & 2 & 3 & 4 & 5 \\
\hline Hace rumores sobre los demás & 1 & 2 & 3 & 4 & 5 \\
\hline Es tímido(a) & 1 & 2 & 3 & 4 & 5 \\
\hline $\begin{array}{l}\text { Es más lento(a) al aprender } \\
\text { cosas nuevas en la escuela }\end{array}$ & 1 & 2 & 3 & 4 & 5 \\
\hline $\begin{array}{l}\text { Deja de hacer su trabajo cuando } \\
\text { se presentan problemas }\end{array}$ & 1 & 2 & 3 & 4 & 5 \\
\hline Es ordenado (a) & 1 & 2 & 3 & 4 & 5 \\
\hline Es bueno(a) en los deportes & 1 & 2 & 3 & 4 & 5 \\
\hline
\end{tabular}




\begin{tabular}{|l|c|c|c|c|c|}
\hline $\begin{array}{l}\text { Le gusta hacer cosas con sus } \\
\text { amigos en vez de con su familia }\end{array}$ & 1 & 2 & 3 & 4 & 5 \\
\hline Es dificil de disciplinar & 1 & 2 & 3 & 4 & 5 \\
\hline Quiere ir bien en la escuela & 1 & 2 & 3 & 4 & 5 \\
\hline Desobedece a los adultos & 1 & 2 & 3 & 4 & 5 \\
\hline $\begin{array}{l}\text { Trabaja bien sin ayuda de los } \\
\text { adultos }\end{array}$ & 1 & 2 & 3 & 4 & 5 \\
\hline
\end{tabular}

III. Dibuje un círculo alrededor del número que muestre la frecuencia con la que su niño(a) ha realizado las siguientes actividades en este año.

\begin{tabular}{|l|c|c|c|c|c|}
\hline $\begin{array}{l}\text { Con qué frecuencia su niño (a) } \\
\text { ha realizado esta actividad }\end{array}$ & Nunca & $\begin{array}{c}\text { Una o } \\
\text { dos } \\
\text { veces }\end{array}$ & $\begin{array}{c}\text { Cerca } \\
\text { de una } \\
\text { vez por } \\
\text { semana }\end{array}$ & $\begin{array}{c}2 \text { o 3 } \\
\text { veces } \\
\text { por } \\
\text { semana }\end{array}$ & $\begin{array}{c}4 \text { o más } \\
\text { días a la } \\
\text { semana }\end{array}$ \\
\hline $\begin{array}{l}\text { Ir al POSJU después de la } \\
\text { escuela }\end{array}$ & 1 & 2 & 3 & 4 & 5 \\
\hline $\begin{array}{l}\text { Tomar clases extras en } \\
\text { matemáticas o español después } \\
\text { de la escuela }\end{array}$ & 1 & 2 & 3 & 4 & 5 \\
\hline $\begin{array}{l}\text { Tomar alguna clase de arte, } \\
\text { baile, deporte o alguna actividad } \\
\text { después de la escuela }\end{array}$ & 1 & 2 & 3 & 4 & 5 \\
\hline $\begin{array}{l}\text { Ir a clases de religión (por } \\
\text { ejemplo catecismo o escuelita } \\
\text { de domingo) o a un servicio } \\
\text { religioso (misa, culto) en su } \\
\text { iglesia, templo o mesquita }\end{array}$ & 1 & 2 & 3 & 4 & 5 \\
\hline $\begin{array}{l}\text { Jugar algún deporte organizado } \\
\text { después de la escuela (por } \\
\text { ejemplo en un equipo de fútbol, } \\
\text { soccer o baloncesto) }\end{array}$ & 1 & 2 & 3 & 4 & 5 \\
\hline $\begin{array}{l}\text { Ir a algún otro tipo de club u } \\
\text { organización después de la } \\
\text { escuela que no se haya } \\
\text { mencionado }\end{array}$ & 1 & 2 & 3 & 4 & 5 \\
\hline
\end{tabular}




\begin{tabular}{|l|l|l|l|l|l|}
\hline $\begin{array}{l}\text { Estar en casa solo(a) después de } \\
\text { la escuela (sin un adulto } \\
\text { presente) }\end{array}$ & 1 & 2 & 3 & 4 & 5 \\
\hline $\begin{array}{l}\text { Cuidar a su(s) hermano(s)(as) } \\
\text { en casa, después de la escuela, } \\
\text { sin un adulto presente }\end{array}$ & 1 & 2 & 3 & 4 & 5 \\
\hline $\begin{array}{l}\text { Pasar el tiempo con sus amigos } \\
\text { después de la escuela sin un } \\
\text { adulto presente }\end{array}$ & 1 & 2 & 3 & 4 & 5 \\
\hline
\end{tabular}

\section{Durante el ano lectivo, Que tanto ha ido su niño(a) al programa POSJU después de la escuela? (Encierre solo uno)}

\begin{tabular}{|l|c|}
\hline Nunca & 0 \\
\hline Una o dos veces & 1 \\
\hline Cerca de una vez por semana & 2 \\
\hline 2-3 dias por semana & 3 \\
\hline 4 o más dias por semana & 4 \\
\hline
\end{tabular}

V. Para cada enunciado, dibuje un círculo alrededor del número que mejor describa lo que usted piensa acerca de POSJU

\begin{tabular}{|l|c|c|c|c|c|}
\hline & $\begin{array}{c}\text { Difiero } \\
\text { compl } \\
\text { e- } \\
\text { tament } \\
\text { e }\end{array}$ & $\begin{array}{c}\text { En } \\
\text { desa- } \\
\text { cuerdo }\end{array}$ & $\begin{array}{c}\text { No } \\
\text { estoy } \\
\text { de } \\
\text { acuerd } \\
\text { o ni } \\
\text { tampo } \\
\text { co en } \\
\text { desa- } \\
\text { cuerdo }\end{array}$ & $\begin{array}{c}\text { De } \\
\text { acuerd } \\
\text { o }\end{array}$ & $\begin{array}{c}\text { Compl } \\
\text { e- } \\
\text { tament } \\
\text { e de } \\
\text { acuerd } \\
\text { o }\end{array}$ \\
\hline $\begin{array}{l}\text { POSJU contribuye a las necesidades de } \\
\text { mi niño(a) }\end{array}$ & 1 & 2 & 3 & 4 & 5 \\
\hline $\begin{array}{l}\text { Mi niño(a) se queja de no tener } \\
\text { suficiente tiempo para sí msimo(a) }\end{array}$ & 1 & 2 & 3 & 4 & 5 \\
\hline $\begin{array}{l}\text { Hay suficientes actividades para que mi } \\
\text { niño(a) escoja que hacer }\end{array}$ & 1 & 2 & 3 & 4 & 5 \\
\hline $\begin{array}{l}\text { Estoy salisfecho(a) con la calidad de } \\
\text { actividades en que mi niño(a) ha } \\
\text { participado este año }\end{array}$ & 1 & 2 & 3 & 4 & 5 \\
\hline A mi niño(a) le gusta ir a POSJU & 1 & 2 & 3 & 4 & 5 \\
\hline
\end{tabular}




\begin{tabular}{|l|c|c|c|c|c|}
\hline Los niños en POSJU son niños buenos & 1 & 2 & 3 & 4 & 5 \\
\hline $\begin{array}{l}\text { El personal de POSJU son importantes } \\
\text { para mi niño }\end{array}$ & 1 & 2 & 3 & 4 & 5 \\
\hline POSJU es un lugar seguro & 1 & 2 & 3 & 4 & 5 \\
\hline $\begin{array}{l}\text { El personal es justo disciplinando a mi } \\
\text { niño según sus reglas }\end{array}$ & 1 & 2 & 3 & 4 & 5 \\
\hline $\begin{array}{l}\text { Me preocupo cuando mi niño(a) está } \\
\text { con este grupo de niños }\end{array}$ & 1 & 2 & 3 & 4 & 5 \\
\hline $\begin{array}{l}\text { El personal me informa como va mi } \\
\text { niño(a) }\end{array}$ & 1 & 2 & 3 & 4 & 5 \\
\hline $\begin{array}{l}\text { Mi niño(a) tiene tiempo de relajarse y } \\
\text { jugar en POSJU }\end{array}$ & 1 & 2 & 3 & 4 & 5 \\
\hline $\begin{array}{l}\text { Mi niño tiene una relación positiva con } \\
\text { el personal }\end{array}$ & 1 & 2 & 3 & 4 & 5 \\
\hline $\begin{array}{l}\text { POSJU ofrece un buen ambiente para } \\
\text { que mi niño(a) haga amistades }\end{array}$ & 1 & 2 & 3 & 4 & 5 \\
\hline $\begin{array}{l}\text { Estoy satisfecho(a) con las horas de } \\
\text { trabajo de POSJU }\end{array}$ & 1 & 2 & 3 & 4 & 5 \\
\hline $\begin{array}{l}\text { POSJU está en un lugar conveniente } \\
\text { para mi niño(a) }\end{array}$ & 1 & 2 & 3 & 4 & 5 \\
\hline $\begin{array}{l}\text { En total, estoy satisfecho(a) con } \\
\text { POSJU }\end{array}$ & 1 & 2 & 3 & 4 & 5 \\
\hline
\end{tabular}


APPENDIX 3

TEACHER STUDENT REPORT 
DATE:

1. Please rate the student's WORKS HABITS. For each item, circle the number that best describes this student.

\begin{tabular}{|l|c|c|c|c|c|}
\hline & $\begin{array}{c}\text { Very } \\
\text { poor }\end{array}$ & $\begin{array}{c}\text { Some- } \\
\text { what } \\
\text { poor }\end{array}$ & $\begin{array}{c}\text { Averag } \\
\mathrm{e}\end{array}$ & Good & $\begin{array}{c}\text { Very } \\
\text { good }\end{array}$ \\
\hline Follows program procedures & 1 & 2 & 3 & 4 & 5 \\
\hline Works well independently & 1 & 2 & 3 & 4 & 5 \\
\hline Works neatly and carefully & 1 & 2 & 3 & 4 & 5 \\
\hline Uses time wisely & 1 & 2 & 3 & 4 & 5 \\
\hline Completes work promptly & 1 & 2 & 3 & 4 & 5 \\
\hline Keeps materials organized & 1 & 2 & 3 & 4 & 5 \\
\hline
\end{tabular}

II. These items ask about the student's SOCIAL SKILLS WITH PEERS. For each item, circle the number that best describes this student.

\begin{tabular}{|l|c|c|c|c|c|}
\hline & $\begin{array}{c}\text { Very } \\
\text { poor }\end{array}$ & $\begin{array}{c}\text { Some- } \\
\text { what } \\
\text { poor }\end{array}$ & $\begin{array}{c}\text { Averag } \\
\mathrm{e}\end{array}$ & Good & $\begin{array}{c}\text { Very } \\
\text { good }\end{array}$ \\
\hline Understands others' feelings & 1 & 2 & 3 & 4 & 5 \\
\hline $\begin{array}{l}\text { Is socially aware of what is } \\
\text { happening in a situation }\end{array}$ & 1 & 2 & 3 & 4 & 5 \\
\hline $\begin{array}{l}\text { Accurately interprets what a peer } \\
\text { is trying to do }\end{array}$ & 1 & 2 & 3 & 4 & 5 \\
\hline $\begin{array}{l}\text { Refrains from over-impulsive } \\
\text { responding }\end{array}$ & 1 & 2 & 3 & 4 & 5 \\
\hline $\begin{array}{l}\text { Generates many solutions to } \\
\text { interpersonal problems }\end{array}$ & 1 & 2 & 3 & 4 & 5 \\
\hline $\begin{array}{l}\text { Is aware of the effects of his/her } \\
\text { behaviors on others }\end{array}$ & 1 & 2 & 4 & 5 \\
\hline $\begin{array}{l}\text { Generates good-quality solutions } \\
\text { to interpersonal problems }\end{array}$ & 1 & 3 & 4 & 5 \\
\hline
\end{tabular}


III. These items ask about this student's BEHAVIOR WITH OTHER CHILDREN. Circle the number for how true each sentence is for the student.

$\left.\begin{array}{|l|c|c|c|}\hline & \text { Not true } & \begin{array}{c}\text { Sometimes } \\ \text { true }\end{array} & \text { Often true } \\ \hline \begin{array}{l}\text { Tends to react to others students' distress } \\ \text { by teasing them or making things worse }\end{array} & 0 & 1 & 2 \\ \hline \text { Seems concerned when other students are } & 0 & 1 & 2 \\ \hline \text { distressed } & 0 & 1 & 2 \\ \hline \text { Is an aggressive child } & 0 & 1 & 2 \\ \hline \text { Taunts and teases other students } & 0 & 1 & 2 \\ \hline \text { Threatens other students } & 0 & 1 & 2 \\ \hline \text { Is kind towards students } & 0 & 1 & 2 \\ \hline \text { Listen to students } & 0 & 1 & 2 \\ \hline \text { Compromises in conflicts with students } & 0 & 1 & 2 \\ \hline \text { Is cooperative with students } & 0 & 1 & 2 \\ \hline \text { Loses temper easily in conflicts with } \\ \text { students }\end{array}\right)$


IV. The next set of items is about this student's TASK PERSISTENCE. Circle the number for how true each sentence is for the student.

\begin{tabular}{|l|c|c|c|c|}
\hline & $\begin{array}{c}\text { Not at } \\
\text { all true }\end{array}$ & $\begin{array}{c}\text { A little } \\
\text { true }\end{array}$ & $\begin{array}{c}\text { Mostly } \\
\text { true }\end{array}$ & $\begin{array}{c}\text { Really } \\
\text { true }\end{array}$ \\
\hline $\begin{array}{l}\text { If the student can't do a job the first time, } \\
\text { he/she keeps trying until he/she can }\end{array}$ & 1 & 2 & 3 & 4 \\
\hline $\begin{array}{l}\text { This student gives up on things before finishing } \\
\text { them }\end{array}$ & 1 & 2 & 3 & 4 \\
\hline $\begin{array}{l}\text { If something looks too hard, this student will } \\
\text { not even bother to try it }\end{array}$ & 1 & 2 & 3 & 4 \\
\hline $\begin{array}{l}\text { This student handles unexpected problems very } \\
\text { well }\end{array}$ & 1 & 2 & 3 & 4 \\
\hline Failure just make this student try harder & 1 & 2 & 3 & 4 \\
\hline $\begin{array}{l}\text { This student is unsure about his/her ability to do } \\
\text { things }\end{array}$ & 1 & 2 & 3 & 4 \\
\hline This student can depend on himself/herself & 1 & 2 & 3 & 4 \\
\hline This student gives up easily & 1 & 2 & 3 & 4 \\
\hline
\end{tabular}


Fecha:

I. Por favor evalúe los HABITOS DE TRABAJO del estudiante, dibuje un círculo alrededor del número que mejor describa a este estudiante

\begin{tabular}{|l|c|c|c|c|c|}
\hline & $\begin{array}{c}\text { Muy } \\
\text { mal }\end{array}$ & $\begin{array}{c}\text { Algo } \\
\text { mal }\end{array}$ & Prome & dio & Muy \\
bien \\
\hline Sigue los procedimientos del programa & 1 & 2 & 3 & 4 & 5 \\
\hline Trabaja claramente y cuidadosamente & 1 & 2 & 3 & 4 & 5 \\
\hline Utiliza su tiempo inteligentemente & 1 & 2 & 3 & 4 & 5 \\
\hline Termina el trabajo puntualmente & 1 & 2 & 3 & 4 & 5 \\
\hline Mantiene sus materiales organizados & 1 & 2 & 3 & 4 & 5 \\
\hline
\end{tabular}

II. La siguiente evaluación se refiere al TRATO SOCIAL CON SUS COMPAÑEROS. Dibuje un círculo alrededor del número que mejor describa a este estudiante

\begin{tabular}{|l|c|c|c|c|c|}
\hline & $\begin{array}{c}\text { Muy } \\
\text { mal }\end{array}$ & $\begin{array}{c}\text { Algo } \\
\text { mal }\end{array}$ & Prome & dio & $\begin{array}{c}\text { Muy } \\
\text { bien }\end{array}$ \\
\hline Entiende los sentimientos de los demás & 1 & 2 & 3 & 4 & 5 \\
\hline $\begin{array}{l}\text { Socialmente, está al tanto de lo que } \\
\text { sucede en una situación }\end{array}$ & 1 & 2 & 3 & 4 & 5 \\
\hline $\begin{array}{l}\text { Interpreta correctamente lo que su } \\
\text { compañero esta tratando de hacer }\end{array}$ & 1 & 2 & 3 & 4 & 5 \\
\hline $\begin{array}{l}\text { Se abstiene de contestar sobre- } \\
\text { impulsivamente }\end{array}$ & 1 & 2 & 3 & 4 & 5 \\
\hline $\begin{array}{l}\text { Genera soluciones a problemas } \\
\text { interpersonales }\end{array}$ & 1 & 2 & 3 & 4 & 5 \\
\hline Esta consciente de los efectos que & 1 & 2 & 3 & 4 & 5 \\
\hline
\end{tabular}




\begin{tabular}{|l|c|c|c|c|c|}
\hline produce su comportamiento & & & & & \\
\hline $\begin{array}{l}\text { Genera soluciones de calidad a los } \\
\text { problemas interpersonales }\end{array}$ & 1 & 2 & 3 & 4 & 5 \\
\hline
\end{tabular}

III. La siguiente evaluación se refiere al COMPORTAMIENTO CON OTROS NIÑOS. Dibuje un círculo alrededor del número que muestre que tan acertada es cada oración para este estudiante

\begin{tabular}{|c|c|c|c|}
\hline & Falso & $\begin{array}{l}\text { A veces } \\
\text { cierto }\end{array}$ & $\begin{array}{l}\text { Usualment } \\
\text { e cierto }\end{array}$ \\
\hline $\begin{array}{l}\text { Tiende a reaccionar a la angustia de su } \\
\text { compañero (a) de manera molesta } \\
\text { empeorando la situación }\end{array}$ & 0 & 1 & 2 \\
\hline $\begin{array}{l}\text { Se muestra interesado o preocupado ante la } \\
\text { angustia de su compañero (a) }\end{array}$ & 0 & 1 & 2 \\
\hline Es agresivo (a) & 0 & 1 & 2 \\
\hline Molesta y se burla de otros estudiantes & 0 & 1 & 2 \\
\hline Amenaza a otros estudiantes & 0 & 1 & 2 \\
\hline Es amable con otros estudiantes & 0 & 1 & 2 \\
\hline Escucha a los estudiantes & 0 & 1 & 2 \\
\hline Se compromete en conflictos con estudiantes & 0 & 1 & 2 \\
\hline Coopera con los estudiantes & 0 & 1 & 2 \\
\hline $\begin{array}{l}\text { Pierde el control fácilmente en conflictos con } \\
\text { estudiantes }\end{array}$ & 0 & 1 & 2 \\
\hline Discute con estudiantes & 0 & 1 & 2 \\
\hline Es amistoso (a) hacia los estudiantes & 0 & 1 & 2 \\
\hline Irrita e incomoda a los estudiantes & 0 & 1 & 2 \\
\hline Interrumpe las actividades de los estudiantes & 0 & 1 & 2 \\
\hline
\end{tabular}




\begin{tabular}{|l|c|c|c|}
\hline $\begin{array}{l}\text { Muestra interés por asuntos morales (por } \\
\text { ejemplo justicia, bienestar de otros) }\end{array}$ & 0 & 1 & 2 \\
\hline $\begin{array}{l}\text { Ofrece su ayuda y consuela estudiantes que } \\
\text { están molestos }\end{array}$ & 0 & 1 & 2 \\
\hline $\begin{array}{l}\text { Continúa molestando a estudiantes que de por } \\
\text { sí están molestos }\end{array}$ & 0 & 1 & 2 \\
\hline
\end{tabular}

\section{La siguiente evaluación se refiere a la PERSISTENCIA DE LA LABOR del estudiante. Dibuje un círculo alrededor del número que muestre que tan cierta es cada oración para el estudiante}

\begin{tabular}{|l|c|c|c|c|}
\hline & Falso & $\begin{array}{c}\text { Poco } \\
\text { cierto }\end{array}$ & $\begin{array}{c}\text { Bastante } \\
\text { cierto }\end{array}$ & $\begin{array}{c}\text { Totalme } \\
\text { nte cierto }\end{array}$ \\
\hline $\begin{array}{l}\text { Si el estudiante no logra hacer su labor } \\
\text { bien, sigue intentando hasta que lo logra }\end{array}$ & 1 & 2 & 3 & 4 \\
\hline $\begin{array}{l}\text { Este estudiante se da por vencido antes } \\
\text { de terminar sus labores }\end{array}$ & 1 & 2 & 3 & 4 \\
\hline $\begin{array}{l}\text { Si algo se ve muy difícil, este estudiante } \\
\text { no se molesta en intentarlo }\end{array}$ & 1 & 2 & 3 & 4 \\
\hline $\begin{array}{l}\text { Este estudiante maneja problemas } \\
\text { inesperados de buena manera }\end{array}$ & 1 & 2 & 3 & 4 \\
\hline $\begin{array}{l}\text { El fallar hace que este estudiante se } \\
\text { esfuerce más }\end{array}$ & 1 & 2 & 3 & 4 \\
\hline $\begin{array}{l}\text { Este estudiante no está seguro (a) de su } \\
\text { habilidad para hacer las cosas }\end{array}$ & 1 & 2 & 3 & 4 \\
\hline $\begin{array}{l}\text { Este estudiante puede depender de sí } \\
\text { mismo (a) }\end{array}$ & & 2 & 3 & 4 \\
\hline Este estudiante se rinde fácilmente & 1 & 2 & 4 \\
\hline
\end{tabular}


APPENDIX 4

ROSENBERG SELF-ESTEEM SCALE 
Date:

Directions: Please circle the number for each question that best describes your agreement with each statement.

\begin{tabular}{|l|c|c|c|c|}
\hline & $\begin{array}{c}\text { Strongly } \\
\text { Agree }\end{array}$ & $\begin{array}{c}\text { Agree } \\
\text { Some- } \\
\text { what }\end{array}$ & $\begin{array}{c}\text { Disagree } \\
\text { Some- } \\
\text { what }\end{array}$ & $\begin{array}{c}\text { Strongly } \\
\text { Disagree }\end{array}$ \\
\hline $\begin{array}{l}\text { I feel that I'm a person of worth, at } \\
\text { least on an } \\
\text { equal par with others. }\end{array}$ & 3 & 2 & 1 & 0 \\
\hline $\begin{array}{l}\text { I feel that I have a number of good } \\
\text { qualities }\end{array}$ & 3 & 2 & 1 & 0 \\
\hline $\begin{array}{l}\text { All in all, I am inclined to feel that } \\
\text { I'm a failure. }\end{array}$ & 3 & 2 & 1 & 0 \\
\hline $\begin{array}{l}\text { I am able to do things as well as most } \\
\text { other people. }\end{array}$ & 3 & 2 & 1 & 0 \\
\hline $\begin{array}{l}\text { I feel I do not have much to be proud } \\
\text { of. }\end{array}$ & 3 & 2 & 1 & 0 \\
\hline $\begin{array}{l}\text { I take a positive attitude toward } \\
\text { myself. }\end{array}$ & 3 & 2 & 1 & 0 \\
\hline $\begin{array}{l}\text { On the whole, I am satisfied with } \\
\text { myself. }\end{array}$ & 3 & 2 & 1 & 0 \\
\hline $\begin{array}{l}\text { I wish I could have more respect for } \\
\text { myself. }\end{array}$ & 3 & 2 & 1 & 0 \\
\hline I certainly feel useless at times. & 3 & 2 & 1 & 0 \\
\hline $\begin{array}{l}\text { At times I think that I am no good at } \\
\text { all. }\end{array}$ & 3 & 2 & 1 & 0 \\
\hline
\end{tabular}

\section{Administrative use only:}

Score

Scorer Name

Program Name 
Fecha:

Circula en cada pregunta el número que mas describe tu sentir en cada una de las declaraciones.

\begin{tabular}{|c|c|c|c|c|}
\hline & $\begin{array}{l}\text { Totalmente } \\
\text { de Acuerdo }\end{array}$ & $\begin{array}{l}\text { De } \\
\text { acuerdo }\end{array}$ & $\begin{array}{l}\text { Desa- } \\
\text { cuerdo }\end{array}$ & $\begin{array}{l}\text { Total- } \\
\text { mente } \\
\text { Desa- } \\
\text { cuerdo }\end{array}$ \\
\hline $\begin{array}{l}\text { Tengo la sensación de que soy una } \\
\text { persona de valía al menos igual que la } \\
\text { mayoría de la gente }\end{array}$ & 3 & 2 & 1 & 0 \\
\hline $\begin{array}{l}\text { Tengo la sensación de que poseo } \\
\text { algunas buenas cualidades }\end{array}$ & 3 & 2 & 1 & 0 \\
\hline $\begin{array}{l}\text { En definitiva, tiendo a pensar que soy } \\
\text { un fracasado }\end{array}$ & 3 & 2 & 1 & 0 \\
\hline $\begin{array}{l}\text { Soy capaz de hacer las cosas tan bien } \\
\text { como la mayoría de las personas }\end{array}$ & 3 & 2 & 1 & 0 \\
\hline $\begin{array}{l}\text { Siento que no tengo demasiadas cosas } \\
\text { de las que sentirme orgulloso }\end{array}$ & 3 & 2 & 1 & 0 \\
\hline $\begin{array}{l}\text { Tengo una actitud positiva hacia mí } \\
\text { mismo }\end{array}$ & 3 & 2 & 1 & 0 \\
\hline $\begin{array}{l}\text { En general, estoy satisfecho conmigo } \\
\text { mismo }\end{array}$ & 3 & 2 & 1 & 0 \\
\hline Ojalá me respetara más a mí mismo & 3 & 2 & 1 & 0 \\
\hline A veces me siento realmente inútil & 3 & 2 & 1 & 0 \\
\hline $\begin{array}{l}\text { A veces pienso que no soy bueno en } \\
\text { nada }\end{array}$ & 3 & 2 & 1 & 0 \\
\hline
\end{tabular}

Uso Administrativo Solamente:

Puntuación:

Número de Estudiante:

Nombre del Programa: 
APPENDIX 5

SOCIAL SKILLS CHECKLIST 
DATE: /

With a checkmark select all the items that applies to you

\begin{tabular}{|l|l|}
\hline \multicolumn{1}{|c|}{ Individual Traits } & \\
\hline I am usually in a positive mood. & \\
\hline I usually come to the program willingly. & \\
\hline I usually cope with rebuffs or other disappointments adequately. & \\
\hline I show interest in others. & \\
\hline I show capacity to empathize & \\
\hline I display the capacity for humor. & \\
\hline I do not seem to be acutely lonely. & \\
\hline & \multicolumn{1}{|c|}{ Peer Relationships } \\
\hline I interact nonverbally with other children with smiles, waves, nods, etc. & \\
\hline I expect a positive response when approaching others. \\
\hline $\begin{array}{l}\text { I express my wishes and preferences clearly; and i give reasons for my actions } \\
\text { and positions. }\end{array}$ & \\
\hline I assert my own rights and needs appropriately. & \\
\hline I am not easily intimidated by bullying. & \\
\hline $\begin{array}{l}\text { I express my frustrations \& anger effectively, without escalating disagreements } \\
\text { or harming others. }\end{array}$ & \\
\hline I gain access to ongoing groups at play and work. & \\
\hline $\begin{array}{l}\text { If I enter an ongoing discussion on a topic; I make relevant contributions to } \\
\text { ongoing activities. }\end{array}$ & \\
\hline I take turns fairly easily. & \\
\hline $\begin{array}{l}\text { I have positive relationships with one or two peers; and show the capacity to } \\
\text { really care about them and miss them if they are absent. }\end{array}$ & \\
\hline $\begin{array}{l}\text { I have "give-and-take" exchanges of information, feedback, or materials with } \\
\text { others. }\end{array}$ & \\
\hline I negotiate and compromise with others appropriately. \\
\hline $\begin{array}{l}\text { I am able to maintain friendship with one or more peers, even after } \\
\text { disagreements. }\end{array}$ & \\
\hline I do not draw inappropriate attention to myself. \\
\hline I accept and enjoy peers and adults who have special needs. \\
\hline $\begin{array}{l}\text { I accept and enjoy peers and adults who belong to ethnic groups other than my } \\
\text { own. }\end{array}$ & \\
\hline \\
and work with. \\
\hline I am usually accepted versus neglected or rejected by other children. \\
\hline I am usually respected rather than feared or avoided by other children. \\
\hline $\begin{array}{l}\text { Sometimes I am invited by other children to join them in play, friendship, and } \\
\text { I am named by other children as someone they are friends with or like to play }\end{array}$ & \\
\hline
\end{tabular}


FECHA:

Con una marca de "Check" selecciona todas las declaraciones que te apliquen

\begin{tabular}{|l|l|}
\hline \multicolumn{1}{|c|}{ Rasgos Individuales } & $\checkmark$ \\
\hline Usualmente estoy de un humor positivo. & \\
\hline Usualmente asisto al programa voluntariamente. & \\
\hline Usualmente hago frente a los fracasos y decepciones adecuadamente. & \\
\hline Demuestro interés hacia los demás & \\
\hline Demuestro capacidad para confraternizar. & \\
\hline Demuestro capacidad para tener sentido de humor. & \\
\hline No aparento estar muy solo. & \\
\hline \multicolumn{1}{|c|}{ Destrezas Sociales } \\
\hline $\begin{array}{l}\text { Interactúo no-verbalmente con otros niños con sonrisas, saludos, asintiendo } \\
\text { con la cabeza, etc. }\end{array}$ & \\
\hline Espero una respuesta positiva cuando me acerco a los demás. & \\
\hline $\begin{array}{l}\text { Expreso mis deseos y preferencias claramente, y justifico mis acciones y } \\
\text { posiciones. }\end{array}$ & \\
\hline Valoro mis derechos y necesidades apropiadamente. & \\
\hline No me intimido fácilmente por otros. & \\
\hline $\begin{array}{l}\text { Expreso mis frustraciones y corajes efectivamente sin escalar en discusiones o } \\
\text { lastimar a otros. }\end{array}$ & \\
\hline Gano acceso a grupos en juegos y en el trabajo. & \\
\hline $\begin{array}{l}\text { Si entro a una discusión sobre un tema, hago contribuciones relevantes hacia } \\
\text { las actividades que se están llevando a cabo. }\end{array}$ & \\
\hline Tomo turnos facilmente. & \\
\hline $\begin{array}{l}\text { Tengo relaciones positivas con uno o dos personas, y demuestro la capacidad } \\
\text { de preocuparme por ellos y extrañarlos si están ausentes. }\end{array}$ & \\
\hline $\begin{array}{l}\text { Tengo intercambios positivos de información, comentarios, o materiales con } \\
\text { otros. }\end{array}$ & \\
\hline Puedo negociar y comprometerme con otros apropiadamente. \\
\hline $\begin{array}{l}\text { Puedo conservar la amistad con una o más personas incluso luego de tener } \\
\text { desacuerdos. }\end{array}$ & \\
\hline No atraigo atención inapropiada hacia mí. & \\
\hline Acepto y disfruto la compañía de adultos que tienen necesidades especiales. & \\
\hline $\begin{array}{l}\text { Acepto y disfruto de la compañía de adultos que perteneces a grupos étnicos } \\
\text { distintos a los míos. }\end{array}$ & \\
\hline \\
\hline Usualmente soy aceptado en vez de ser rechazado por otros niños. \\
\hline Usualmente soy respetado en vez de ser temido o evitado por otros niños. \\
\hline A veces soy invitado por otros niños a jugar, a formar amistades y a trabajar. & \\
\hline $\begin{array}{l}\text { Otros niños me consideran como alguien que es su amigo (a) y a alguien con } \\
\text { guienabajar y jugar. }\end{array}$ & \\
\hline
\end{tabular}


FECHA:

Con una marca de "Check" selecciona todas las declaraciones que te apliquen

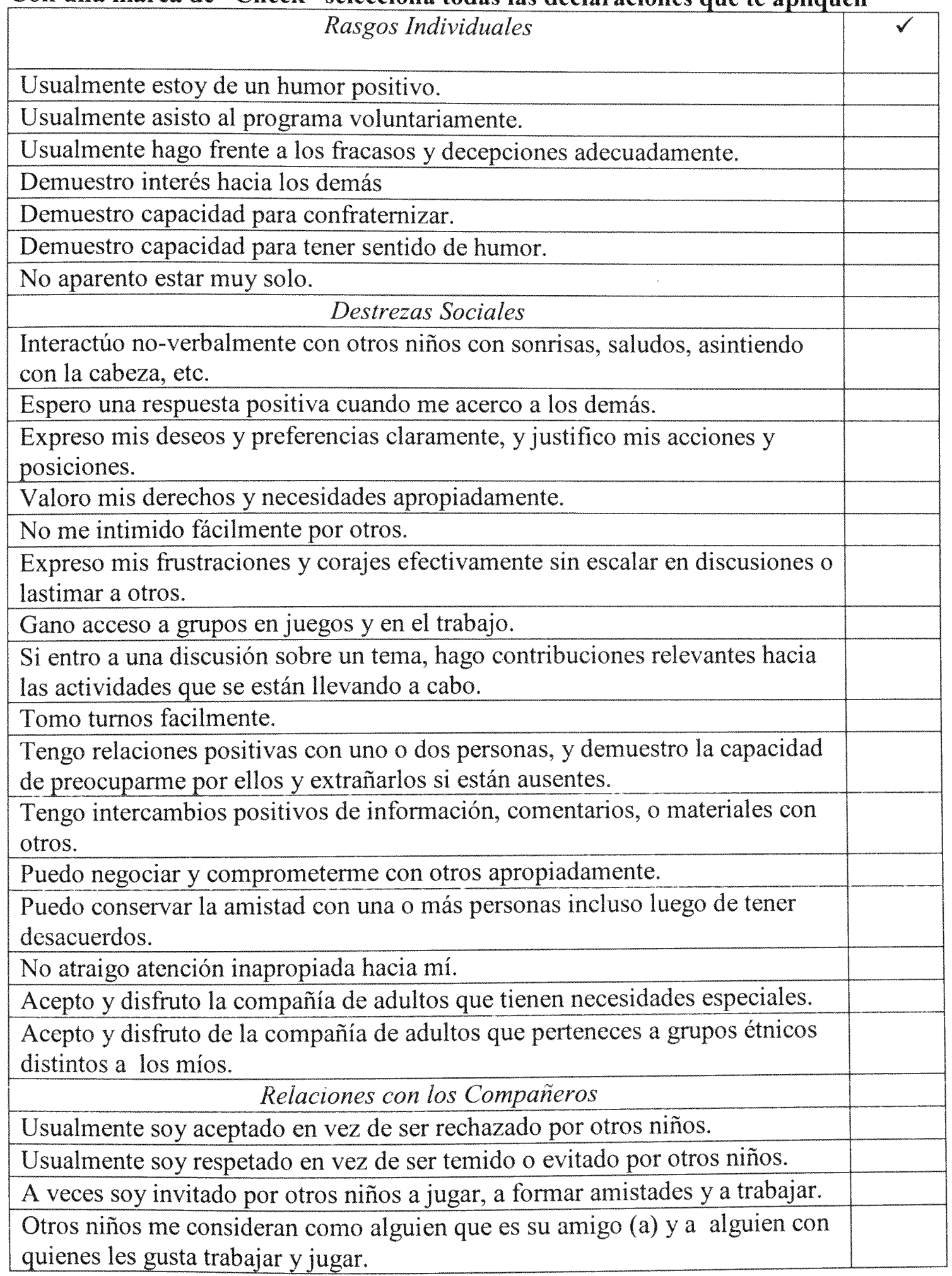

